\title{
DERIVATION OF ES CELLS FROM EARLY STAGE PREIMPLANTATION EMBRYOS AND CHARACTERISATION OF THEIR CARDIAC DIFFERENTIATION POTENTIAL IN MICE
}

\author{
Bag $S^{*}$, , Pfannkuche $K^{1}$, Krzyzak $V^{2}$, Wagner $B^{2}$, Sachinidis $A^{1}$ and Hescheler $J^{1}$
}

Most murine embryonic stem cell lines have been derived from the inner cell mass of blastocysts and extensively studied in different aspects including generation of organ specific cells. However, no detailed studies have been made on cardiac specific gene expression, immunocytochemical and electrophysiological characterisation of cardiomyocytes generated from early stage (preimplantation) embryo derived embryonic stem cells in mice. In the present study, new embryonic stem cell lines were derived from early stage preimplanatation embryos in mice. In vitro differentiation of such cell lines readily generated cardiomyocytes, which expressed different cardiac specific genes in a temporally regulated manner as well as cardiac cells specific proteins. This is probably the first report, which showed the temporal pattern of cardiac specific genes as well as protein expression in cardiac cells generated from in vitro differentiation of preimplantation embryo derived ES cells.

\section{Introduction}

Since the discovery of the embryonic stem (ES) cells in mice in early eighties ${ }^{[1,2]}$, a number of stem cell lines have been derived in different species including human being. Providing specific culture conditions, ES cells can be maintained in undifferentiated state for a prolonged period of time.$^{[3,4,5,6]} \mathrm{An}$ important characteristic of ES cells is their ability to undergo a spontaneous differentiation in vitro $[3,7,8,9]$ forming a variability of progenitors and differentiated cells. The ability of ES cells to differentiate into any tissue represents an enormous therapeutic potential to treat different diseases. Further, the remarkable characteristic of ES cells to contribute germ line transmission has paved the way for generating transgenic animals more efficiently. ${ }^{[10]}$

Apart from inner cell mass (ICM), ES cells have been derived from very early stage embryos in different species including human being. $[11,12,13,14,15,16]$ The analysis of these cells was mainly focused on different aspects of pluripotency. ES cell derived from early stage embryos may have added advantage than that of blastocyst derived ES cells not only in therapeutics, but also in animal reproduction. This is because the stage of embryonic development at which ES cells are derived seems crucial to their subsequent function in experimental models and cell therapy. ${ }^{[14,17]}$ For example, the preblastocyst period in murine development constitutes a time when blastomeres are not yet committed to either ICM or the trophectoderm lineage. ${ }^{[18]}$ Therefore, it is assumed that ES cells derived from morula or even more earlier stage embryos could exhibit a broader differentiation potential than those of ICM or epiblast derived ES cells ${ }^{[14]}$. This could primarily be the result of variation in epigenetic status of the ES cells as epigenetic memory of the embryo used to derive ES cells may influence the developmental potential of the ES cells obtained. ${ }^{[14]}$ The epigenetic changes would be more in blastocyst derived ES cells than morula derived ES cells as extended in vitro culture are known to cause methylation defects that can result in abnormal embryo development. ${ }^{[19]}$ At the morula stage, both parental genomes are hypo-methylated and genome wide de novo methylation occurs at the blastocyst stage preferentially in the ICM. [20]

In the present study we report the derivation of new ES cell lines from early stage murine preimplantation embryos which readily exhibit cardiac differentiation potentiality.

\section{Materials and Methods}

\section{Mice and embryos}

129/ SvPassico (I29S2/SvPassCrl) male and female mice 


\section{RESEARCH ARTICLE}

(Charles River, Germany) were used in the present study. Mice were kept on a light dark cycle of $12: 12 \mathrm{hr}$ regime with dark period from 6.30PM to 6.30AM. Blastocyst for ES cell injections were obtained from BL6=C57BL6 mice. BL6/BalbC female were used as recipients for embryo transfer. All the embryos were flushed from the uterine horns with M2 medium (Sigma-Aldrich, Munich, Germany).

\section{Superovulation and embryo collection}

The adult 129/ SvPassico strain of mice were superovulated with injection of 5IU PMSG (Intervet) followed by 5IU human chorionic gonadotrophin (Intervet) after about $48 \mathrm{hrs}$ of PMSG injection. Injected females were placed with $129 /$ SvPassico male and mating was confirmed in the next morning by the presence of vaginal plug.

\section{Culture of embryos and ES cell derivation}

The culture of embryos and derivation of ES cell lines were done as described by Tesar. ${ }^{[14]}$ Briefly, morula stage embryos were isolated from 3.0 pc (post coital) mice. The zona pellucida of embryos was removed with brief exposure to Tyrodes saline acidified to $\mathrm{pH} 2.5$. ${ }^{[21]}$ The zona pellucida-free embryos were placed on inactivated CF1 feeder $\left(0.2 \times 10^{6}\right.$ /well $)$ in 6 well tissue culture plates. The culture medium used was DMEM (Invitrogen) with 15\% fetal bovine serum (Sigma), 2mM L-glutamine (Invitrogen), $0.1 \mathrm{mM}$ 2-mercaptoethanol (Invitrogen), $1 \times$ non-essential amino acids (Invitrogen) and 1000 units/ml recombinant murine leukaemia inhibitory factor (ESGRO, Chemicon) in a humidified incubator at $5 \% \quad \mathrm{CO}_{2}$ and $37^{\circ} \mathrm{C}$. Penicillinstreptomycin (Invitrogen) was used only for culture of CF1 feeder and zona-free embryos but culture of established ES cell lines was always done in ES cell medium without antibiotics. Entire cell colonies formed by the individual embryos were cut manually by the tip of a needle and aspired with a fine glass pipette. The individual cell clones derived from embryos were put in drop of PBS (phosphate buffered saline) for serial washing to remove medium with serum. The washed cell clones were put into droplets of $0.05 \%$ trypsin-EDTA (Invitrogen) for about five minutes at $37^{\circ} \mathrm{C}$. The cell clumps were gently pipetted in and out through a fine glass tube and remaining large clumps were mechanically dissociated into small clumps by the tip of a needle. The dissociated cells as well as small cell clumps were put onto a fresh inactive CF1 feeder-layer in a 6-well culture dish in ES cell medium. After 4-6 days, cells were passaged again with trypsin-EDTA onto a fresh feeder layer. Resulting ES cell colonies were propagated 3 to 4 times depending on the number of cells before they were cryopreserved in liquid nitrogen. Cryopresevation of ES cells was done by suspending ES cells in freezing medium having $90 \%$ FBS and $10 \%$ dimethyl sulfoxide (DMSO, Sigma). The ES cells were kept in $-80^{\circ} \mathrm{C}$ for $48 \mathrm{hrs}$ and then transferred in liquid nitrogen vapour.

\section{Immunocytochemistry}

For immunostaining, the ES cells were cultured about $48 \mathrm{~h}$ or till small colonies of ES cells were formed on cover slips. The cells were washed with PBS twice and then fixed with absolute methanol for 15 minutes at room temperature. The cells were then blocked with $5 \%$ bovine serum albumin (BSA) in PBS for one hour at room temperature. The cells were again washed with PBS for 30 minutes at 10 minutes interval. After washing, the cells were incubated at $4^{\circ} \mathrm{C}$ overnight with primary antibodies diluted in $1 \%$ BSA in PBS. After washing with PBS, the cells were again incubated with fluorescent secondary antibodies (Molecular probes, 1:1000) along with DAPI (1:2000) for $1 \mathrm{hr}$ at room temperature. The cells were further washed with PBS for 30 minutes with changing PBS at 10 minutes interval and mounted with antifading agent (Pro Long Gold, Molecular probes). The primary antibodies used were: mouse monoclonal primary antibody against Oct-3/4 (Santa Cruz biotechnology, INC; 1:200), goat polyclonal Nanog (1:40) (Santa Cruz biotechnology, INC), mouse monoclonal SSEA-1 (MC-480, Developmental studies Hybridoma Bank; 1:400) and mouse monoclonal SSEA-3 (MC-631, Developmental studies Hybridoma Bank; 1:400). Alkaline phosphatase staining was done as described. ${ }^{[22]}$

\section{Flow cytometry}

After about 48 hrs of culture, ES cells were trypsinised and a single cell suspension was prepared. Cell clumps were removed by passing through a cell sieve. The ES cells were immunostained with PE conjugated primary antibody SSEA-1 (Sigma). A parallel isotype control was also run. Acquisition of 20,000 cells was done with a FACScan (BD Biosciences, Heidelberg, Germany) and the data analysis was done with CellQuest software (Becton Dickinson, Heidelberg, Germany) for calculating SSEA-1 positive cells.

\section{Sexing of ES cells}

For sexing, genomic DNA was isolated from all the five cell lines. Sexing was done by PCR using Ychromosome specific primer sequence (See table below).

\section{Chromosome count}

The number of chromosomes was studied in different cell lines by giemsa staining as per the protocol of Department of Genetics, School of Medicine, University of Pennsylvania, USA. In brief, ES cells after 2 days of passage were arrested in the metaphase by adding colcemid $(0.02 \mu \mathrm{g} / \mathrm{ml}$ at a final concentration, PPA laboratories, Pasching, Austria) to the culture medium for $1 \mathrm{hr}$. The cells were treated with trypsin-EDTA for $5 \mathrm{~min}$ at $37^{\circ} \mathrm{C}$. After vigorous pipetting, the single cell suspension was centrifuged at $500 \mathrm{~g}$ for $5 \mathrm{~min}$. The pellet was exposed to hypotonic shock by $0.56 \% \mathrm{KCL}$ solution for 10 minutes at room temperature. After centrifugation at $500 \mathrm{~g}$ for $5 \mathrm{~min}$, the hypotonic solution was removed and the pellet was loosend via gently flicking and fixed with methanolacetic acid (3:1). After $5 \mathrm{~min}$, the suspension was 
The list of primers used for amplification of each transcript were:

\begin{tabular}{|c|c|c|}
\hline Name & Primer sequence & Product size \\
\hline$A-M H C$ & $\begin{array}{l}\text { F-----GATGGCACAGAAGATGCTGA } \\
\text { R-----CTGCCCCTTGGTGACATACT }\end{array}$ & $120 \mathrm{bp}$ \\
\hline$B-M H C$ & $\begin{array}{l}\text { F-----CCCTCCTCACATCTTCTCCA } \\
\text { R----GCGGCAATAACAGCAAAATA }\end{array}$ & $150 \mathrm{bp}$ \\
\hline Gata-4 & $\begin{array}{l}\text { F-----TCAAACCAGAAAACGGAAGC } \\
\text { R-----GTGGCATTGCTGGAGTTACC }\end{array}$ & $107 \mathrm{bp}$ \\
\hline$N K \times 2.5$ & $\begin{array}{l}\text { F----CCACTCTCTGCTACCCACCT } \\
\text { R----CCAGGTTCAGGATGTCTTTGA }\end{array}$ & $107 \mathrm{bp}$ \\
\hline CTnT & $\begin{array}{l}\text { F-----GAGGAGGTGGTGGAGGAGTA } \\
\text { R-----GGCTTCTTCATCAGGACCAA }\end{array}$ & $150 \mathrm{bp}$ \\
\hline$M L C 2 v$ & $\begin{array}{l}\text { F-----AAAGAGGCTCCAGGTCCAAT } \\
\text { R-----TCAGCCTTCAGTGACCCTTT }\end{array}$ & $140 \mathrm{bp}$ \\
\hline Nanog & F-----CAAAACCAAAGGATGAAGTGC & $111 \mathrm{bp}$ \\
\hline Oct4 & $\begin{array}{l}\text { F----AGGAAGCCGACAACAATGAG } \\
\text { R----GAGCAGTGACGGGAACAGAG }\end{array}$ & $429 \mathrm{bp}$ \\
\hline Nestin & $\begin{array}{l}\text { F------GGAAGAAGTTCCCAGGCTTC } \\
\text { R-----ATTAGGCAAGGGGAAGAGA }\end{array}$ & $139 \mathrm{bp}$ \\
\hline AFP & $\begin{array}{l}\text { F-----CCA GAA CCT GCC GAG AGT TGC } \\
\text { R-----GCC TTC AGG TTT GAC GCC ATT }\end{array}$ & 552bp \\
\hline$C d X 2$ & $\begin{array}{l}\text { F-------GATACATCACCATCAGGAGGAAA } \\
\text { R-------CAAGGAGGTCACAGGACTCAAG }\end{array}$ & $236 b p$ \\
\hline Tbrachyury & $\begin{array}{l}\text { F-----CAT GTA CTC TTT CTT GCT GG } \\
\text { R-----GGT CTC GGG AAA GCA GTG GC }\end{array}$ & $313 \mathrm{bp}$ \\
\hline Y chromosome & $\begin{array}{l}\text { F-------GTA GGA AGA ATC TTT CTC ATG CTG G } \\
\text { R------TTT TTG AGT GCT GAT GGG TGA CGG }\end{array}$ & $313 \mathrm{~kb}$ \\
\hline GAPDH & $\begin{array}{l}\text { F----GGTGCTGAGTATGTCGTGGA } \\
\text { R--- CGGAGATGATGACCCTTTTG }\end{array}$ & $97 \mathrm{bp}$ \\
\hline
\end{tabular}

centrifuged again for 5 min. Fixation was performed twice prior to spreading the cells on ice cold slides. The slides were air-dried, stained in freshly made Giemsa (Carl Roth, Germany) for 30-40 min and rinsed with tap water. Some slides were also stained with Hoechst dye for $10 \mathrm{~min}$, washed with water and examined under a fluorescence microscope.

\section{Production of chimeric mice}

About 10-15 ES cells were introduced into the blastocoel cavity (BL6=C57BI6) by microinjection using micromanipulator (Carl Zeiss). After microinjection, the blastocysts were cultured for 2-2.5 hrs in $\mathrm{CO}_{2}$ incubator before being transferred into pseudopregnant (BL6/BalbC) foster mothers. Chimeric progeny were identified on the basis of their brown coat color.

\section{In vitro differentiation of ES cells}

The differentiation ability of the newly derived ES cells was examined by suspension ${ }^{[23]}$ as well as hanging drop culture ${ }^{[24]}$. Briefly, for hanging drop culture, an ES cell suspension of $2.5 \times 10^{4}$ cells $/ \mathrm{ml}$ was prepared in differentiation medium (IMDM supplemented with $20 \%$ fetal calf serum, $1 \%$ non-essential amino acids , $2 \mathrm{mmol} / \mathrm{l} \mathrm{L}-$ glutamine, and $100 \mu \mathrm{mol} / \mathrm{l} \beta-\mathrm{ME})$. Of this ES cell suspension, $20 \mu \mathrm{l}$ was spotted on the inside of the upper lid of a $10 \mathrm{~cm}$ bacteriologic dish and then covered over its bottom dish containing $5 \mathrm{ml}$ phosphate-buffered saline. For mass culture, about one million ES cells were suspended in $10 \mathrm{ml}$ of differentiation medium and agitated in bacteriological dishes. On day 2, the multicellular aggregates (EBs) that have formed were transferred to new dishes with $10 \mathrm{ml}$ differentiation medium kept in culture up to day 19 with changing medium periodically. For transgenic cell lines (see below), medium was supplemented with $5 \mu \mathrm{g} / \mathrm{ml}$ puromycin (Sigma-Aldrich) on day 8 or 9 of culture to select for cardiomyocytes. Medium was changed every 2-3 days. Selection was continued till day 20 of differentiation.

\section{Generation of transgenic ES cell lines for cardiac lineage selection}

For cardiac lineage selection, $\mathrm{BHK}-1$ was used to generate transgenic ES cell lines. For this purpose, the aPIG vector described by Kolossov et al.1998 ${ }^{[25]}$ was used. The aPIG vector contains an expression cassette for puromycinacetyltransferase under control of the cardiac specific alpha myosin heavy chain promoter. The coding sequence for enhanced green fluorescent protein (eGFP) is hooked up via an internal ribosome entry site to the puromycinacetyltransferase sequence. The $\alpha \mathrm{PIG}$ vector was linearised by Sacl restriction enzyme. About $40 \mu \mathrm{g}$ of this vector DNA was used for transfection. The transgenic cells were selected using geneticin $(400 \mu \mathrm{g} / \mathrm{ml}$, Invitrogen). The transgenic clones were propagated at least 4 times before differentiating them into beating EBs. Twelve transgenic clones were differentiated in vitro and assayed for the formation of 
beating areas and eGFP expression. Clone five (CL-5) was selected for further characterisation of EBs and ES cellderived cardiomyocytes.

Culture of cardiomyocytes and whole EB of transgenic BHK-1 for immunostaining

The beating EBs were gathered under a microscope and collected in a $15 \mathrm{ml}$ tube. The EBs were treated for 20-30 minutes at $37^{\circ} \mathrm{C}$ with $1 \mathrm{ml}$ of collagenase- $B(1 \mathrm{mg} / \mathrm{ml}$, Roche Diagnostics $\mathrm{GmBH}$, Germany) with intermittent pipetting. After incubation, the cell suspension was gently resuspended to achieve single cell suspension. Cells were washed with differentiation medium. The cell pellet was resuspended in differentiation medium and plated on fibronectin-coated cover slips. Plated cells were cultured for 3-4 days. Further, a collection of EBs having beating one were cultured on gelatin coated $(0.1 \%$ in PBS) cover slip in differentiation medium for about $48 \mathrm{hrs}$ for their attachment.

\section{Immunostaining of cultured cardiomyocytes and EBs}

The cultured cardiomyocytes and attached EBs were washed with PBS and fixed with 99\% methanol for 15 minutes at room temperature. After fixation, cells were blocked with 5\% BSA (Sigma) in PBS for $1 \mathrm{hr}$ and washed for 30 minutes with PBS after changing PBS at 10 minutes interval. The cultured cardiomyocytes and EBs were incubated with primary antibodies singly or in combination viz. a-actinin, a-actinin+desmin, $\alpha$-actinin+connexin-43, aactinin+vimentin and $\alpha$-actinin+cardiac troponin-l. After washing with PBS for $30 \mathrm{~min}$ at $10 \mathrm{~min}$ interval, cultured cardiac cells and EBs were incubated with fluorescentlabelled secondary antibodies (Molecular probes) for $1 \mathrm{hr}$. The cells and EBs were washed thoroughly with PBS and mounted with antifade reagent (Molecular probes). The fluorescence staining was observed using a Zeiss Axiovert 200 (Zeiss, Jena, Germany). The primary antibody used were anti mouse alpha-actinin (IgG1, 1:800, Sigma); anti mouse desmin (IgG1, 1:100,Neomakers, Fremont, CA), anti mouse vimentin (IgM, 1:200, Sigma-Aldrich), antimouse connexin-43 (IgM, 1:400, Sigma-Aldrich), antimouse monoclonal anti cardiac toponinl (IgG2b, 1:200, Chemicon).

RNA isolation from ES cells and differentiating EB during different days of in vitro culture.

For studying the expression of oct-4 and nanog, total mRNA was isolated from about one million cells of each five ES cell clones. After about 48 hrs of culture, cells were trypsinized, spun down and used for isolation of total RNA. About 40-50 EBs were collected on different days of differentiation (described above) between day-0 (ES cells) and day-19 of culture. Prior to RNA isolation, EBs were dissociated into single cells using $0.05 \%$ trypsin. Total RNA was prepared using the pure link micro to midi Total RNA purification kit (Invitrogen).

Reverse transcription PCR (RT-PCR) analysis of marker gene expression in ES cells and differentiating EBs Analysis of Oct3/4, Nanog, nestin, AFP, cdX2, T-brachury and different cardiac specific genes viz. $\alpha-M H C, \beta-M H C$, Gata-4, NKx2.5, CTnT, MLC2v were performed by RT-PCR cDNA was synthesized from $\sim 1 \mu \mathrm{g}$ of total RNA using superscript II reverse transcriptase (Invitrogen, Karlsruhe,
Germany). cDNA samples were subjected to PCR amplification with primers selective for different transcripts. The Jumpstart Red Taq ready master mix (Sigma) was used in the PCR. The PCR protocol was followed as: $94^{\circ} \mathrm{C}-2 \mathrm{~min}$; $94^{\circ} \mathrm{C}-35 \mathrm{~s} ; 56-58^{\circ} \mathrm{C}$ for $45 \mathrm{~s} ; 72^{\circ} \mathrm{C}-1 \mathrm{~min} 45 \mathrm{~s}$; step 2 to 4 were repeated 29 to 35 times; $72^{\circ} \mathrm{C}-5 \mathrm{~min}$; hold $-4^{\circ} \mathrm{C}$. The PCR products were size fractionated by $2 \%$ agarose gel electrophoresis and visualized by ethidium bromide staining.

\section{Results and Discussion}

\section{Derivation of ES cells and their characterisation}

Zona free embryos were plated on inactivated CF1 feeder (conditioned with ES cell medium) in 6-well culture dishes. The embryos were not disturbed until day 4 or 5 when they had formed colonies on the feeder layer (Fig.1A$\mathrm{G})$. Most of the embryos attached to the feeder within $24 \mathrm{hrs}$. Few embryos developed a blastocyst-like structure having a single layer of cells surrounding the embryos and a cell mass in one pole. These embryos also formed primary colonies. It took about 19 to 31 days to derive ES cell lines from morula stage embryos including 4 to 5 passages of the individual clones and cryopreservation of the cells (Table 1). Five independent cell lines (BHK-1, 2, 3, 4 and 5) were derived from culture of 22 morula stage embryos, which was about $22.7 \%$ of the total embryos cultured (Table 2). The newly derived ES cell colonies are shown in Figure $1 \mathrm{H}$. The cell lines were passaged every 48h. All five ES cell lines were positive for alkaline phosphatase and stained positive for ES cell specific markers SSEA-1, SSEA-3, Nanog and Oct-3/4 (Fig. 2 A-E). These ES cells also expressed the transcription factors Nanog and Oct-3/4 (Fig. 2F). FACS analysis revealed about $94.0 \%, 94.2 \%, 91.4 \%, 88.7 \%$ and $67.7 \%$ SSEA-1 positive cells for BHK-1 to BHK-5, respectively.

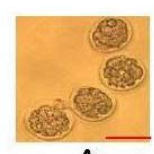

A

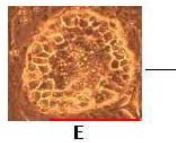

E

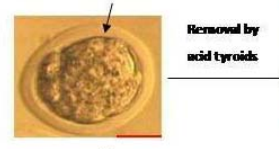

B
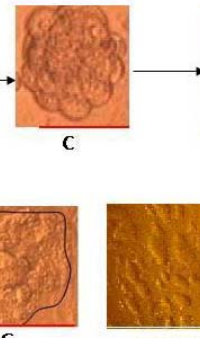

G

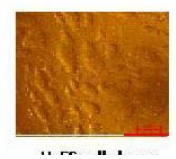

Fig. 1. Derivation of ES cells from early stage murine embryos (morula). Fig $A$ to $G$ indicates the sequntial events during culture of murine early stage embryos. (A ,B): Day-0 Morula (20x), (C): Morula after ZP removal, (D): Morula after Day-1 of culture, $(E)$ : Morula after Day-3 of culture, $(F)$ : Morula after Day-4 of culture, (G): Morula after Day-5 of culture (10x), (H): Established new cell colonies (4x).
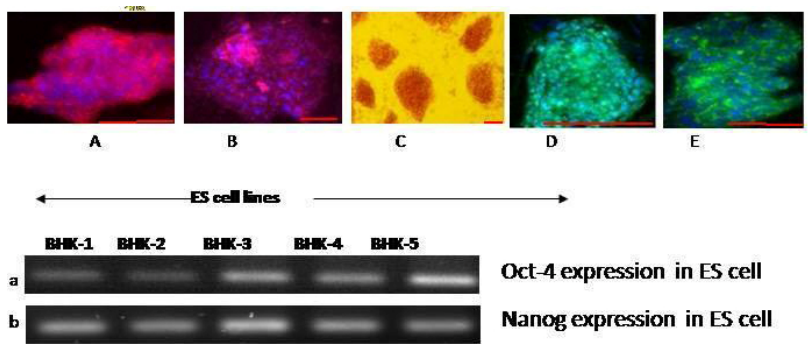

Oct-4 expression in ES cell

Nanog expression in ES cell

Fig. 2. Immunohistochemical (A-E) and transcriptional expression (F) of different stem cell specific markers in newly derived cell lines in mice. (A):SSEA-1 (40x), (B):SSEA-3 (20x), (C): Alkaline phosphatase (10x), (D): Oct-3/4 (63x), (E): Nanog (40x), (F): Expression of Oct4 (a), Nanog (b) in BHK -1,2,3,4,5, (c)-GAPDH. 
RESEARCH ARTICLE

Table 1. Time taken for derivation of ES cells from morula of mice

\begin{tabular}{|l|l|l|l|l|l|l|l|l|}
\hline $\begin{array}{l}\text { ES cell } \\
\text { name }\end{array}$ & $\begin{array}{l}\text { Date of } \\
\text { Embryo } \\
\text { culture }\end{array}$ & $\begin{array}{l}\text { Ist } \\
\text { passage } \\
\text { (After) }\end{array}$ & $\begin{array}{l}\text { 2nd } \\
\text { passage } \\
\text { (After) }\end{array}$ & $\begin{array}{l}\text { 3rd } \\
\text { passage } \\
\text { (After) }\end{array}$ & $\begin{array}{l}\text { 4th } \\
\text { passage } \\
\text { (After) }\end{array}$ & $\begin{array}{l}\text { 5th } \\
\text { passage } \\
\text { (After) }\end{array}$ & $\begin{array}{l}\text { 6th } \\
\text { passage } \\
\text { (After) }\end{array}$ & $\begin{array}{l}\text { Time taken for first } \\
\text { freezing (From date } \\
\text { of embryo culture) }\end{array}$ \\
\hline $\begin{array}{l}\text { BHK-1 } \\
\text { (Morula) }\end{array}$ & D-0 & D-7 & D-10 & D-15 & D-17 & $\begin{array}{l}\text { D-19 } \\
\text { (Frozen) }\end{array}$ & & 19 Days \\
\hline $\begin{array}{l}\text { BHK -2 } \\
\text { (Morula) }\end{array}$ & D-0 & D-3 & D-10 & D-15 & $\begin{array}{l}\text { D-19 } \\
\text { (Frozen) }\end{array}$ & & & 19 days \\
\hline $\begin{array}{l}\text { BHK-3 } \\
\text { (Morula) }\end{array}$ & D-0 & D-3 & D-7 & D-10 & D-15 & $\begin{array}{l}\text { D-22 } \\
\text { (Frozen) }\end{array}$ & & 22 Days \\
\hline $\begin{array}{l}\text { BHK-4 } \\
\text { (Morula) }\end{array}$ & D-0 & D-7 & D-15 & D-19 & D-23 & D-26 & $\begin{array}{l}\text { D-30 } \\
\text { (Frozen) }\end{array}$ & 30 Days \\
\hline $\begin{array}{l}\text { BHK-5 } \\
\text { (Morula) }\end{array}$ & D-0 & D-4 & D-15 & D-24 & D-29 & $\begin{array}{l}\text { D-31 } \\
\text { (Frozen) }\end{array}$ & & 31 days \\
\hline
\end{tabular}

Table 2. Table showing derivation of ES cell lines from early stage murine embryos

\begin{tabular}{|l|l|l|l|l|}
\hline $\begin{array}{l}\text { STRAIN OF } \\
\text { MICE }\end{array}$ & \multicolumn{2}{|l|}{ NUMBER OF EMBRYOS CULTURED } & \multicolumn{2}{l|}{$\begin{array}{l}\text { NO OF ES CELL LINE DERIVATION } \\
\text { FROM }\end{array}$} \\
\hline & Morula & Blastocyst & Morula & Blastocyst \\
\hline Him-1 & 33 & 14 & 0 & 0 \\
\hline 129 SV/Passico & 22 & & & $\ldots$
\end{tabular}

Sexing, karyotyping and production of chimeric mice:

Out of five ES cell lines, 4 were male and one was female genotype (Fig.3A). Chromosome counting by giemsa analysis revealed that BHK-1, 2 and 3 contain 40 chromosomes within $90.90 \%(n-11), 65.51 \%(n=29)$ and $91 \%$ of the spreads. ES cell line BHK-4 was found to contain 38 chromosomes per cell in $87.5 \%$ of the chromosomal spreads $(n=24)$ (Fig. 3B, Table 3). BHK-5 $(n=38)$ showed abnormal karyotype with more than 40 chromosomes per cell.

BHK-1 and 2 were injected into blastocysts and gave rise to chimeric mice. The BHK-1 was injected in 60 blastocysts and produced 4 chimeras whereas BHK-2 was injected into 44 blastocysts and produced 4 chimera (Fig. 3C, 3D).

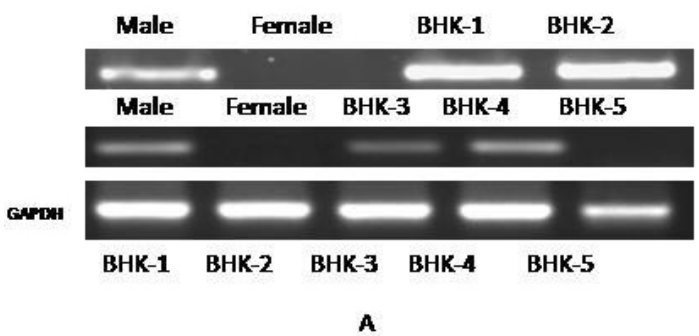

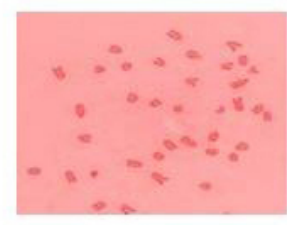

B

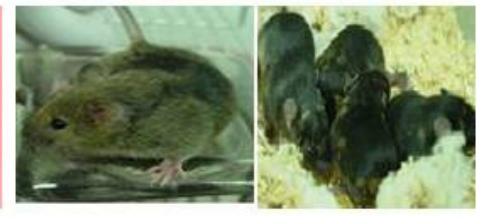

C
D

Fig. 3. Showing sexing (A), chromosomal spread (B) and generation of chimeric mouse (C-BHK-1, D-BHK-2) from new cell lines (See text for detail). 


\section{RESEARCH ART ICLE}

Table 3. Chromosome numbers in newly derived ES cells.

\begin{tabular}{|c|c|c|c|c|c|c|c|c|c|c|c|}
\hline \multirow[t]{2}{*}{ Cell line } & \multicolumn{11}{|c|}{ Chromosome numbers } \\
\hline & & 38 & 39 & 40 & 41 & 42 & 43 & 56 & 77 & 76 & 80 \\
\hline BHK-1 & P10 & & & $(90.10 \%)$ & & & & & & & $9.9 \%$ \\
\hline BHK-2 & P28 & 10.34 & $6.89 \%$ & $65.51 \%$ & 13.79 & & & & $12.5 \%$ & & \\
\hline BHK-3 & $\mathrm{P} 7$ & & & $91 \%$ & & & & & & & \\
\hline BHK-4 & $\mathrm{P} 7$ & 87.5 & $6.25 \%$ & & & & & & & & \\
\hline BHK-5 & & \multicolumn{10}{|c|}{ Diploid and as well as abormal chromosomal number(38-80) } \\
\hline
\end{tabular}

In vitro differentiation of ES cells and genomic expression

Since the methylation of such morula derived ES cells might be different than ICM derived ES cells, we tested the differentiation capacity. Cells of all five lines generated embryoid bodies when cultured in suspension or in hanging drops in differentiation. BHK-1 was tested for the expression of key markers of the three germ layers. The expression of ectodermal (Nestin), mesodermal (T-brachyury), endodermal $(A F P, c d x 2)$ and cardiac (Nkx2.5) cell specific genes during in vitro differentiation were tested for BHK-1(Fig. 4). The expression of $A F P$ and $c d x 2$ were observed from day-7 and day-4 onwards. T-brachyury was expressed on day 4 and 5 only, while the expression of Nkx2.5 was detected from day5 onwards. Nestin was present at all days of differentiation.

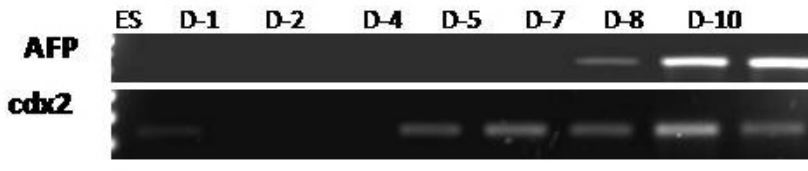

T-Brachyry

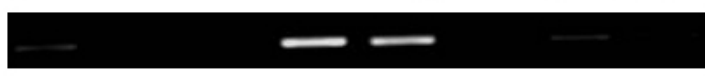

Nkx2.5

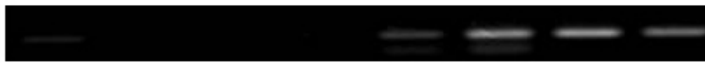

GAPDH

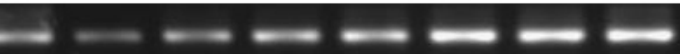

Fig. 4. Genomic expression during differentiation of ES cells derived from morula as a marker for multipotencv in mice strain (BHK-1)

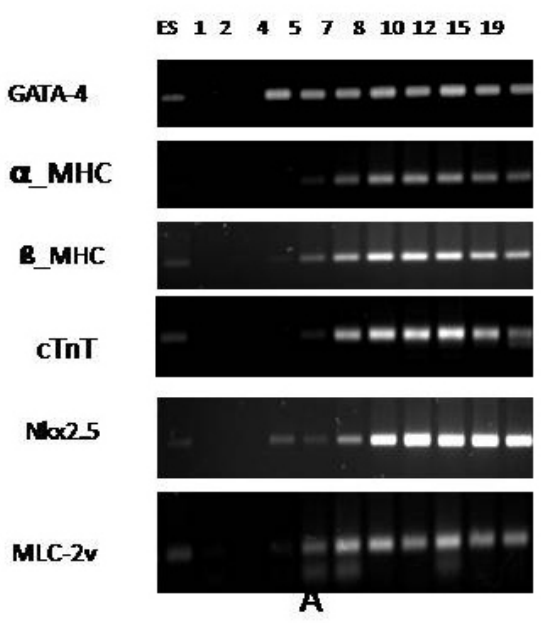

The expression of $\alpha-M H C, \beta-M H C, c T n T, N k x 2.5$, GATA-4 and $M L C 2 v$ were analysed during the development of BHK-1 and BHK-2 EBs. In BHK-1 EBs, the expression of GATA-4 and $N k x 2.5$ started on day-4, $\beta-M H C$ and $M L C 2 v$ from day- 5 onwards while the expression of $\alpha-M H C, c T n T$ was observed from day-7 onwards (Fig.5A). In BHK-2, the expression of GATA-4 was observed from day-5 onwards, while $\alpha-M H C, \beta-$ $M H C, c T n T$ were started from day-7 onwards. MLC2v expression was observed beginning on day-8 (Fig. 5B).

In vitro differentiation of transgenic ES cells and immunocytochemistry of cardiac specific marker proteins.

BHK-1 ES cell line was transfected with a cardiac lineage selection construct to express eGFP and puromycinacetyltransferase under the control of the cardiac specific alpha myosin heavy chain promoter (see materials and methods for details). Twelve stable transfected clones were chosen randomly for in vitro differentiation. Four clones showed beating embryoid bodies and one clone showed maximum beating embryoid bodies with GFP expression (Fig. 6A,6B, 6C). In the other three clones, the GFP expression was detectable in a small number of EBs as well as in small areas of beating EBs. The clone exhibiting higher GFP expression in EBs during differentiation was used for immunostaining and electrophysiological studies. The
GAIA-4

a MHC

B_MHC

cTnT

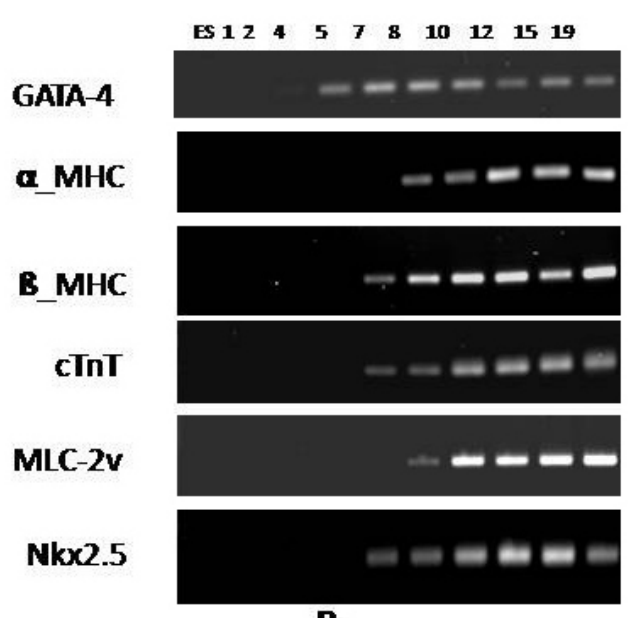

B
Fig. 5. Cardiac specific genomic expression during differentiation of ES cells derived from morula ( A-BHK-1. B- BHK-2) in mice. 


\section{RESEARCH ARTICLE}

cultured cells (Fig.6D, 6E) of beating EBs expressed various cardiac specific marker and gap junctional proteins viz. $\alpha-$ actinin, desmin, connexin-43, vimentin and cardiac troponinl (cTnl) and Titin (Fig.7). Similarly, the attached beating EBs also expressed i.e. $\alpha$-actinin, cTnl, connexin-43 desmin and, vimentin (Fig.7).

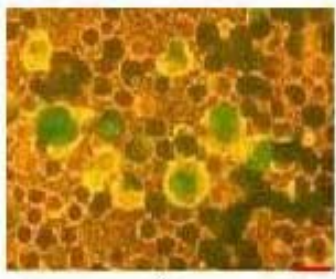

A

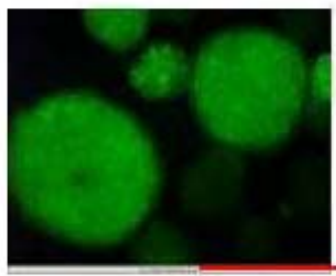

B

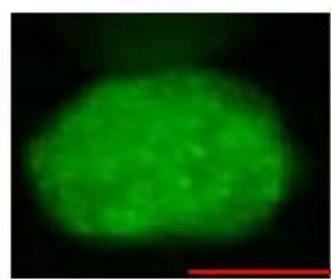

C
SV129 strain of mice ${ }^{[26]}$ while only 2.0 and $2.96 \%$ have been reported for C57BL/6 and BALB/c strain, respectively. ${ }^{[27]} \mathrm{We}$ could not derive ES cells from Him-OF1 (Table 2), neither from morula nor blastocyst (results not shown). The establishment of ES cells not only differs with culture condition ${ }^{[27]}$ but also with strain of mice. ${ }^{[28,29]}$ We observed a formation of primary colonies by morula of Him-OF1 strain mice but it was impossible to split the primary colonies with

Fig. 6. GFP expression in beating EB under puromycin selection in transgenic cell line-1. (A): Day 14 of differentiation (4x), (B): Day-15 of differentiation $(32 X),(C)$ : Day-24 of differentiation (32X), (D): Cardiac cells from puro selected beating EBs during culture (32X), (E): Cardiac cells showing GFP exnrecsinn du urina r. ulture (32X)

The present study was aimed at understanding the characteristics of ES cells derived from early stage preimplantation embryos in murine species. It took an average of 19 to 31 days to derive the ES cells after culture of morula stage embryos (Table 1). The percentage of ES cell derivation was about $23 \%$ of the total embryos cultured (Table 2). A frequency of $10-30 \%$ has been reported for

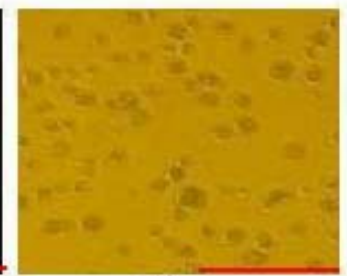

D

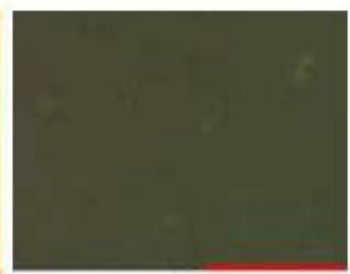

E
$0.05-0.25 \%$ trypsin-EDTA, pronase $(0.5 \%)$ or different types of collagenase because of the presence of fibrous matrix embedding the cells of primary culture. When some of the colonies were again plated after trypsinisation on CF1 feeder, the colonies they formed behaved similarly. We concluded that derivation of ES cell lines in Him-OF1 strain is quite difficult with the protocol followed here.

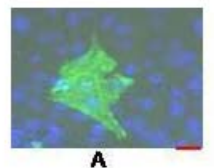

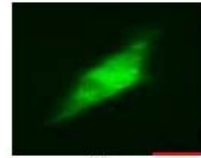

B

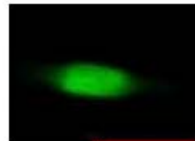

C

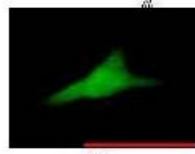

D
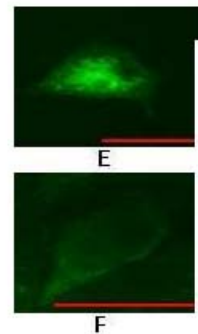

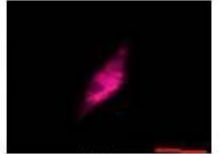

B1

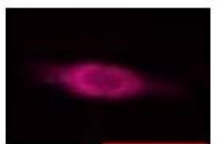

C1

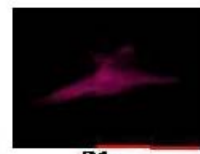

D1
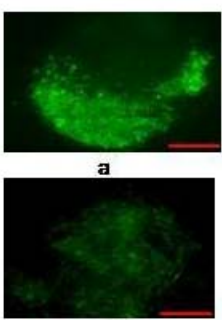

c

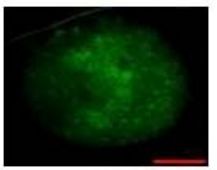

d

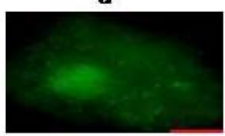

$\mathbf{e}$
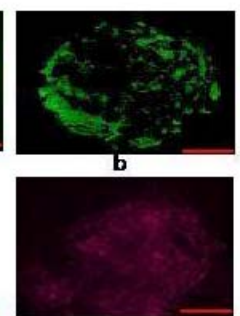

$\mathbf{c 1}$

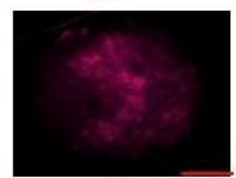

d1

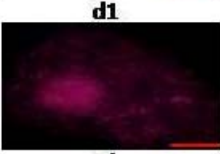

e1

Fig.7.

Immunocytochemical localisation of cardiac specific protein expression in cultured cardiomyocytes (A-F, Scale bars; $10 \mu \mathrm{m}$ ) and embryo bodies (a-e1, Scale bars; $20 \mu \mathrm{m}$ ). A: alpha-actinin; B-B1: B-alpha-actinin (green), B1-Desmin (red)

C-C1: C-alpha-actinin (green), C1-Connexin-43(red)

E:Cardiomyocytes with cTnI

$\mathrm{F}$ :Cardiomyocytes with titin

a:alpha-actinin, b:cTnI, c-alpha-actinin (green), c1-Connexin-43(red)

d-d1:d-alpha-actinin (green), d1-Desmin (red), e-el:e-alpha-actinin (green),

el-Vimentin (red)

Fig.7. Immunohistochemical localisation of cardiac specific sarcomeric protein expression in cultured cardiomyocytes (A-F) and Embryo bodies (a-e1).

(A): alpha-actinin, (B-B2): B-alpha-actinin (20x), B- Desmin (20x), (C-C1): C- alpha-actinin (40x), C1-Connexin-43(40x), (D-D1):D-alphaactinin (40x), D1-Vimentin (40x); (E): Cardiomyocytes with cTnl (40x), (F):Cardiomyocytes with Titin (63x)

(a): alpha-actinin (10x), (b): cTnl(10x), (c-c1): c-alpha-actinin (10x), c1-Connexin-43(10x); (d-d1): d-alpha-actinin (10x), d1-Desmin (10x), (e-e1) : e-alpha-actinin (10x), e1-Vimentin(10x) 
All the five ES cell lines derived from SV129 morulae showed positive immunostainings for SSEA-1, SSEA-3, Oct-4 and Nanog as well as alkaline phosphatase activity (Fig. 2). These results indicated that the newly derived independent cell lines satisfied some criteria for pluripotent cells which are exhibited by the ICM derived ES cell lines i.e. D3. The majority of our ES cell lines had a normal karyotype in more than $80 \%$ of the cells (Table 3 ). These data are well above the normal range $(35 \%-73 \%)$ for normal ES and nuclear transfer-ES cell lines. ${ }^{[30,31,32,33]}$ ES cell lines having more than $40 \%$ of cells with a normal karyotype have been suggested to be efficient for germ line transmission due to successful segregation of chromosomes throughout meiosis $[12,31]$

All the five cell lines formed embryoid bodies, which is a criterion of pluripotent ES cells derived from ICM. In the present study key markers were examined to confirm the ability of the morula derived ES cells to form different body cells- a pointer of pluripotency. During in vitro differentiation, the embryoid bodies of morula derived ES cells exhibited expression of genes specific for three germ layers i.e. ectoderm, endoderm and mesoderm (Fig. 4). Previous studies have also shown that differentiating embryoid bodies from ICM derived ES cells express different germ layer specific genes. ${ }^{[34]}$ However, these ES cells have less potentiality to contribute to trophoblastic cells which makes them pluripotent but not totipotent ${ }^{[35]}$. Morula derived ES cells because of their more primitiveness can make trophoblastic cells more readily which has been partially proven by the result of cloning experiments where blastomeres from morula resulted more live births of cloned animals than ICM cells or cultured ICM cells. ${ }^{[36,37]}$

The expressions of cardiac specific genes (Fig. 5A and 5B) were not quite similar as compared to ICM derived cells as reported earlier. ${ }^{[38]}$ Interestingly, the expression of Nkx2.5 were little delayed (Fig.5A,5B) in the morula derived ES cells. ${ }^{[38]}$ In the present study, the expression of GATA-4, B-MHC and MLC2v was earlier in morula derived embryonic stem cells than ICM derived ES cells. This may indicate that morula derived ES cells may be better in generation of cardiac cells than ICM derived ES cells. The ES cell derived cardiomyocytes express cardiac gene products in a developmentally controlled manner that recapitulate the development of cardiomyocytes from very early cardiac precursor cells (Nkx2.5, $\alpha$-cardiac-actin and GATA-4) to terminally differentiated cells ( $\alpha$ - and $\beta$-cardiac myosin heavy chain (MHC) ${ }^{[39]}$ (a-tropomyosin) ${ }^{[40]}$, myosin light chain $2 \mathrm{v}$ (MLC-2v) ${ }^{[41]}$, atrial natriuretic factor and type $B$ natriuretic factor. ${ }^{[42]}$ These genes express phenotypes of atria (atrial natriuretic factor, a-heavy chain myosin, atrial light chain myosin) and ventricular cardiomyocytes (ventricular myosin light chain). The first gene to display enhanced expression has been observed as GATA-4 ${ }^{[43]}$ a transcription factor known for its significant role in regulating different genes involved in the differentiation and development of the heart [44] As in early myocardial development, mRNAs encoding GATA-4 and Nkx2.5 transcription factors appear in differentiating EBs before mRNAs encoding myosin light chain (MLC-2v), alpha-myosin heavy chain ( $\alpha-\mathrm{MHC})$, betamyosin heavy chain ( $\beta-\mathrm{MHC}$ ) and cardiac troponin-T (cTnT) ${ }^{[38]}$ In the present study, almost similar temporal expression pattern were observed in both the cell tested (BHK-1 and BHK-2). This is probably the first report in expression profile of cardiac specific genes in morula derived ES cells in mice.
In conclusion, the ES cells derived from early stage murine embryos were able to differentiate easily towards cardiac lineages. This is probably the first report which showed the temporal pattern of cardiac specific genes as well as protein expression in cardiac cells derived ES cells developed from very early stage murine embryos.

\section{ACKNOWLEDGEMENT:}

We thank Department of Biotechnology, Government of India for providing financial support as fellowship to the first author for working in the Institute of Neurophysiology, University of Cologne, Germany.

\section{References}

1. Evans MJ, Kaufman MH. Establishment in culture of pluripotent cells from mouse embryos. Nature; 1981; 292:154-156.

2. Martin A. Isolation of pleuripotent stem cell line from early mouse embryos cultured in medium conditioned by teratocarcinoma stem cells. Proc Natl Acad Sci; 1981; 78:7634-7638

3. Doetschman T, Eistetter H, Katz M,Schmidt W, Kemler R. The in vitro development of blastocyst-derived ES cell lines: formation of visceral yolk sac, blood islands and myocardium. J Embryology and Exp Morphology; 1985;87:27-45.

4. Suda Y, Suzuki M, Auzava S. Mouse ES cells exhibits in definite proliferative potential. J Cell Physiol; 1987; 133:197-201.

5. Gardner RL, Brook FA. Reflections on the biology of ES cells (ES). International J Dev Biol; 1997; 41:235-243.

6. Wang ZQ, Kiefer F, Urbanek P. Generation of completely ES cell-derived mutant mice using tetraploid blastocyst injection. Mechanism of Development; 1997; 62:137-145.

7. Chen U. Differentiation of mouse ES cells to lymphohemapoitic lineages in vitro. Developmental Immunology; 1992;2:29-50.

8. Keller GM. In vitro differentiation of ES cells. Current opinion in Cell Biology; 1995; 7: 862-869.

9. Bautch VL, Stanford WL, Rapoport R Russell S, Byrum RS,Futch TA. Blood island formation in attached cultures of murine ES cells. Developmental Dynamics; 1996;205:112.

10. Robertson EJ. Using ES cells to introduce mutations into mouse sperm line. Biol Reprod; 1991; 44 :238-245.

11. Strelchenko N, Stice S. Bovine embryonic pleuripotent cell lines derived from morula stage embryos. Theriogenology; 1994; 41:304 (Abstr).

12. Delhaise $F$, Bralion $V$, Schuurbiers $N$, Dessy $F$. Establishment of an ES cell line from 8-cell stage mouse embryos. European J Morphology; 1996; 34:237-243.

13. Mitalipova M, Beyhan Z, First NL. Pluripotency of bovine embryonic cell line derived from precompacting embryos. Cloning; 2001; 3: 59-67.

14. Tesar PJ. Derivation of germ-line-competent ES cell lines from preblastocyst mouse embryos. PANAS; 2005; 102:8239-8244.

15. Chung Y, Klimanskaya I, Becker S,Marh J, Lu SJ, Johnson J, Meisner L, Lanza R. Embryonic cell lines derived from single mouse blastomeres. Nature; 2006 439: 216-219.

16. Majumdar AC, Sadhan Bag and Swain A. Development of totipotent stem cells from in vitro derived embryos and their characterization in goat. Indian J Anim Prod; 2005; $37: 16-21$

17. Sukoyan MA, Vatolin SY, Golubitsa AN, Zhelezova AL, Semenova LA, Serov OL . ES cells derived from morulae, inner cell mass, and blastocysts of mink: comparisons of their pluripotency. Mol Reprod Dev. 1993; 36:148-58.

18. Ziomek CA, Johnson $\mathrm{MH}$, Handyside $\mathrm{AH}$. The developmental potential of mouse 16 cell blastomeres. J Exp Zool; 1982; 221:345-355. 
19. Shi $W$ and Haaf $T$. Abberant methylation patterns at the two cell stage as an indicator of early developmental failure. Mol Reprod Dev; 2002; 63: 329-334.

20. Dean W, Santos F, Stojkovic M, Zakhartchenko V, Walter $\mathrm{J}$, Wolf E, Reik W. Conservation of methylation reprogramming in mammalian development: aberrant reprogramming in cloned embryos. Proc Natl Acad Sci; 2001;98:13734-13738.

21. Nicolson GL, Yanagimachi R, Yanagimachi H. Ultra structural localisation of lectin binding sites on the zonae pellucida and plasma membranes of mammalian eggs. $J$ Cell Biol; 1975; 66:263-274

22. Lee CK, Moore T, Scales N, Westhusin M, Newton G. Isolation and genetic transformation of PGC derived cells from cattle, goats, rabbits, and rats. Asian-Australasian $\mathrm{J}$ Anim Sci; 2000; 13:587-594.

23. Kurt P, Wunderlich FT, Doss MX, Spitkovsky D,Reppel M, Sachinidis A, Hescheler J. Generation of a double flourescnt double selectable Cre/loxP indicator vector for monitoring of intracellular recombination events. Nature Protocol; 2008; 3:1510-1526

24. Xavier Doss M, Johannes W, Chen S, Hippler Altenburg R, Sotiriadou I, Halbach M, Pfannkuche K, Liang H, Schulz $\mathrm{H}$, Hummel $\mathrm{O}$, et al . Global transcriptome analysis of murine ES cell-derived cardiomyocytes. Genome Biol; 2007; 8:R56

25. Kolossov E, Fleischmann BK, Liu Q,Bloch W,ViatchenkoKarpinski S, Manzke O, Ji GJ, Bohlen H,Addicks K, Hescheler j. Functional characteristics of ES cell-derived cardiac precursor cells identified by tissue-specific expression of the green fluorescent protein. J Cell Biol; 1998; 143: 2045-2056.

26. Abbondanzo SJ, Gadi I, Stewart CL. Derivation of embryonic stem cell lines. In: Wasserman, P.M.; Demamphilis, ML, ed. Methods enzymology, Vol.225. san Diego, CA: Academic Press; 1993:803-823. 33

27. Baharvand $\mathrm{H}$, Matthaei KI. Culture condition difference for establishment of new ES cell lines from the C57/6 and Balb/c mouse strain. In vitro Cell Dev Biol; 2004; 40:7681.

28. Suzuki O, Matsuda J, Takano K, Yamamoto Y, Asano T, Naiki M, Kusanagi M. Effect of genetic background on establishment of mouse ES cells. Exp Anim; 1999; 48: 213-216.

29. Kawase HE, Suemori H, Takahashi N, Okazaki K, Hashimoto K, Nakatsuji N. Strain difference in establishment of mouse embryonic stem (ES) cell lines. Int J D Biol; 1994; 38: 385-390

30. Wakayama S, Takafusa H, Rinako $\mathrm{S}$ et al. Efficient Establishment of Mouse ES Cell Lines from Single Blastomeres and Polar Bodies. Stem Cells; 2007; 25:986-993.
31. Suzuki H, Kamada N, Ueda O. Germ-line contribution of ES cells in chimeric mice: Influence of karyotype and in vitro differentiation ability. Exp Anim; 1997; 46:17-23.

32. Wakayama S, Jakt ML, Suzuki M.. Equivalency of nuclear transfer derived ES cells to those derived from fertilized mouse blastocysts. Stem Cells; 2006; 24:2023-2033.

33. Mitalipova MM, Rao RR, Hoyer DM, Johnson JA, Meisner LF, Jones KL, Dalton S, Stice SL. Preserving the genetic integrity of human ES cells. Nat Biotechnol; 2005; 23:1920.

34. Boheler KR, Wobus AM. Myocardial aging and stem cell biology. In: Mattson MP, Van Zant G, eds, Stem cells: A cellular Fountain of Youth. New York, NY, Elsevier Science; 2001, pp141-177.

35. Wobus AM. Potential of ES cells. Mol Aspects Med; 2001; 22:149-164

36. Heyman $\mathrm{Y}$ and Renard JP. Cloning of domestic species. Anim Reprod Sci; 1996; 42:427-436.

37. Stice SL, Strelchenko NS, Keeper CL and Matthews I. Pluripotent bovine ES cell lines direct embryonic development following nuclear transfer. Biol Reprod; 1996; 54:100-110.

38. Boheler KR, Czyz J, Tweedie D, Yang HT, Anisimov SV, Wobus AM. Differentiation of pluripotent ES cells into cardiomyocytes. Cir Res; 2002; 91:189-201.

39. Sanchez A, Jones WK, Gulick J Doetchman T, Robbins J. Myosin heavy chain gene expression in mouse embryoid bodies: An in vitro developmental study. J Biol Chem; 1991; 266: 22419-22426.

40. Muthuchamy M, Pajak L, Howles P, Doetscham T, Wieczorek DF. Developmental analysis of tropomyosin gene expression in ES cells and mouse embryos. Mol Cell Biol; 1993; 13: 3311-3323.

41. Miller-Hance WC, LaCorbiere M, Fuller SJ, Evans SM, Lyons G, Schmidt C, Robbins J, Chien KR.. In vitro chamber specification during ES cell cardiogenesis. Expression of the ventricular myosin light chain-2 gene is independent of heart tube formation. J Biol Chem; 1993; 268: 25244

42. Boer $\mathrm{PH}$. Activation of the gene for type-b natriuretic factor in mouse stem cell cultures induced for cardiac myogenesis. Biochem Biophys Res Commun; 1994;199:954-961.

43. Segev $H$, Kenyagin-Karsenti $D$, Fishman $B, Z i s k i n d a ~ G N$, Amit M, Coleman R, Itskovitz EJ. Molecular analysis of cardiomyocytes derived from human ES cells. Develop Growth Differ; 2005; 47: 295- 306.

44. Durocher D, Nemer M. Combinatorial interactions regulating cardiac transcription. Dev Genet; 1998; 22, 250-262.

Corresponding author:

\# Sadhan Bag, Center of Advance Studies in Veterinary Physiology, Division of Physiology \& Climatology, Indian Veterinary Research Institute, Bareilly, UP-243122, India 